\title{
Poisoning Due to Datura Inoxia Tea
}

Datura Inoxia Çayına Bağlı Zehirlenme

\section{Seda Özkan, Ömer Salt, Afşin İpekçi, Ali Düzgün, İbrahim İkizceli}

Erciyes Üniversitesi Tıp Fakültesi, Acil Tıp Anabilim Dall, Kayseri

\begin{abstract}
Introduction: Datura inoxia is an ornamental plant belonging to the Solanaceae family. Ingestion of the plant's flowers, leaves, or seeds can result in serious intoxication and even death. Datura inoxia can cause acute anticholinergic poisoning.

Case: We report a case of female who had ingested Datura inoxia (moonflower) seed tea to protect from H1N1 infection and presented to the emergency department with a decreased level of consciousness and difficulty to speech.

Conclusion: As a result, poisons due to vary plants increased. Datura inoxia intoxication should be considered in case of patients who presented with agitation, seizures and delirium.
\end{abstract}

Keywords: Alkaloids, Datura inoxia, Poisoning

\section{ÖZET}

Giriş: Datura inoxia Solanaceae ailesine ait bir süs bitkisidir. Bitkinin çiçeğinin, yapraklarının ve çekirdeklerinin ağızdan alımı ciddi zehirlenmelere hatta ölümlere yol açabilir. Datura inoxia akut antikolinerjik zehirlenmeye yol açabilir.

Olgu: Biz H1N1 enfeksiyonundan korunmak için Datura inoxia (ay çiçeği) çekirdeğinin çayını içtikten sonra şuur seviyesinde azalma ve konuşma zorluğu ile acil servise getirilen bir bayan hastayı olgu olarak sunduk. Sonuç: Sonuç olarak farklı bitkilerle oluşan zehirlenmeler artmıştır. Ajitasyon, nöbet ve deliryumla gelen hastalarda Datura inoxia zehirlenmesinin de düşünülmesi gerekir.

Anahtar kelimeler: Alkaloidler, Datura inoxia, Zehirlenme

Iletişim Adresi ve Sorumlu Yazar:

Seda ÖZKAN

Erciyes Üniversitesi Tip Fakültesi Acil Tip Anabilim Dalı, Talas 38039 Kayseri - Türkiye

E-mail: sedacil@yahoo.com

Telefon: 05426317313 


\section{INTRODUCTION}

Datura inoxia, like other Datura species, contains the highly toxic alkaloids atropine, scopolamine and hyoscyamine in the seeds, roots, flowers and stems ${ }^{(1)}$. The mechanism of toxicity is competitive blockade of acethylcholine at muscarinic receptors, both centrally and peripherally, as well as at end organ sites of the parasympathetic nervous system (2). Datura inoxia is found common around Turkey and can cause acute anticholinergic poisoning and death in humans. The treatment of this poisoning is mainly supportive care and gastrointestinal decontamination with activated charcoal ${ }^{(1,2,3)}$.

Datura inoxia intoxication should be considered in case of patients who presented with agitation, seizures and delirium.

\section{CASE REPORT}

A sixty eight year old female patient was admitted to Emergency Department (ED) with sudden difficulty to speech and a decreased level of consciousness. Patient had no drug using story. Past medical history was unremarkable. She had been hallucinating, agitating, and talking to people who were not there. She was brought to ED by her neighbors after being found lying on the floor of her house. Initially her vital signs were; temperature $36,4{ }^{\circ} \mathrm{C}$, pulse rate 110 beats/ min, respiratory rate 16 breaths $/ \mathrm{min}$, blood pressure $122 / 80$ mmHg and oxygen saturation $96 \%$ on room air. Her Glaskow Coma Scale was 12 and her pupils were $6 \mathrm{~mm}$, sluggish and had no response to light. In order to treat the agitation $5 \mathrm{mg}$ diazepam was given with slow infusion in 3 minutes. Bowel peristalsis was decreased. The lungs were clear and cardiac examination revealed tachycardia. Her ECG was sinusal tachycardia. Patient's blood tests were normal. Then a head CT was performed to eliminate an intracranial pathology that can cause such a similar situation. It was normal. We have monitorized the patient and began symptomatic and supportive therapy. In the next a few hours she had been agitated a few times and we have used total $15 \mathrm{mg}$ diazepam for sedation. In the two hour of the admitting to the ED patient's daughter came to ED and gave some information about the patient. She said that the last night her mother ingested a couple of tea that was prepared with seeds of a plant which she had never seen before with advice of her neighbour to protect from $\mathrm{H}_{1} \mathrm{~N}_{1}$ infection. After then she brought the plant and seeds and we saw that it was Datura inoxia (Figure 1,2). Patient's agitation lasted approximately 12 hours and mydriasis resolved fully after 36 hours after the admission to the ED. After 48 hours from admitting the patient was discharged from the ED without any sequel.

\section{DISCUSSION}

Most of the plants and plant products are potentially lethal, with local and systemic effects ${ }^{(1)}$. Datura species can result in severe toxicity. Each plant varies in the concentrations of alkaloid substances (2). Ingestion of Datura manifests as a classic anticholinergic syndrome comprising central and peripheral signs and symptoms. Central toxic effects include confusion, agitation, anxiety, hallucinations, seizures and coma. Peripheral toxic effects include dry mucous membranes, thirst, flushed face, blurred vision, hyperthermia, urinary retantion, and decreased gut motility ${ }^{(1,2)}$. Symptoms of Datura inoxia toxicity occur typically within 60 minutes after ingestion and continue for $24-48$ hours. But in our case the symptoms began almost 8 hours after ingestion. Because daughter of the patient said that her mother was normal when she leaved the house in the morning ${ }^{(2)}$.

Treatment of anticholinergic toxicity is largely supportive. First of all gastric lavage and active charcoal may helpfull for decontamination. Agitation should be controlled by titrated intravenous benzodiazepines. Haloperidol should be used cautiously in acute intoxications because it may cause acute dystonia and other movement disorders. The role of physostigmine, a naturally occurring acethylcholine esterase inhibitor, has been controversial in the management of anticholinergic overdose. This is due to the potential adverse effects of physostigmine secondary to acethylcholine accumulation $^{(3)}$.

The case presented here demonstrate the difficulties in the diagnosis of Datura inoxia poisoning. The patient was found unconscious in the house. In the absance of any anamnesis made difficult to diagnose. The uniqueness of our case was that the symptoms of the patient began after almost 8 hours from ingestion. The effects of Datura inoxia may be easily remembered by the following mnemonic ; "Blind as a bat, mad as a hatter, red as a beet, hot as a hare, dry as a bone, bowel and bladder lose their tone, and the heart runs alone $"(4,5)$. Among the people of our country, datura species are used as herbal medicine. Cigarettes prepared from the leaves are used in asthma and bronchitis. Seeds are used in acne, eczema, hemorrhoids ${ }^{(6)}$.

In recent years, especially in the media, the use of plant protection and treatment against diseases recommended programs has increased. This affects large masses and people unconsciously take various plants and are consumed. Also people are fear and panic because of pandemic $\mathrm{H}_{1} \mathrm{~N}_{1}$ influenza. Our patients ingested Datura inoxia to protect from $\mathrm{H}_{1} \mathrm{~N}_{1}$ infection.

As a result, poisons due to vary plants increased. ED workers should be aware that anticholinergic plant ingestion not uncommon in the population. This is especially true for aged who uses plants to treat and protect from diseases. 


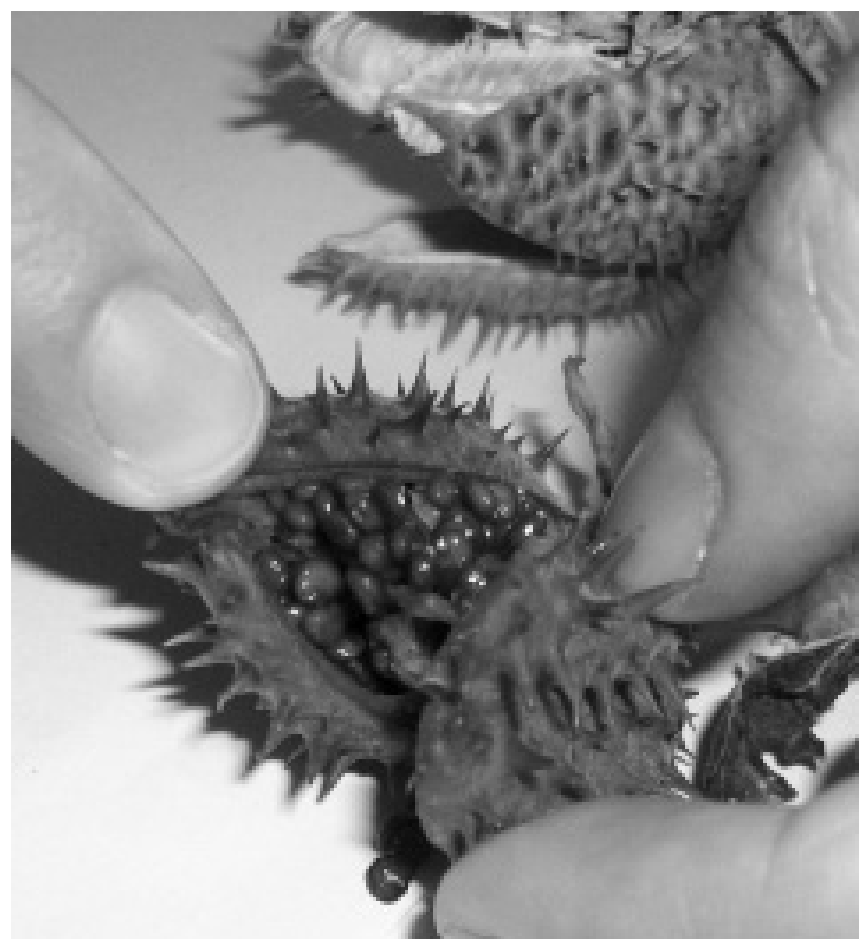

\section{REFERENCES}

1. Raman SV, Jacob J. Mydriasis due to Datura inoxia. Emerg Med J 2005;22:310-11.

2. Center of Disease Control and Prevntion. Suspected moonflower intoxication-Ohio, 2002. MMWR Morb Mortal Wkly Rep. 2003;52:788-91.

3. Wiebe TH, Sigurdson ES, Katz LY. Angel's Trumpet (Datura stramonium) poisoning and delirium in adolescent in Winnipeg, Manitoba:Summer 2006. Pediatr Child Health. 2008;13:193-6.

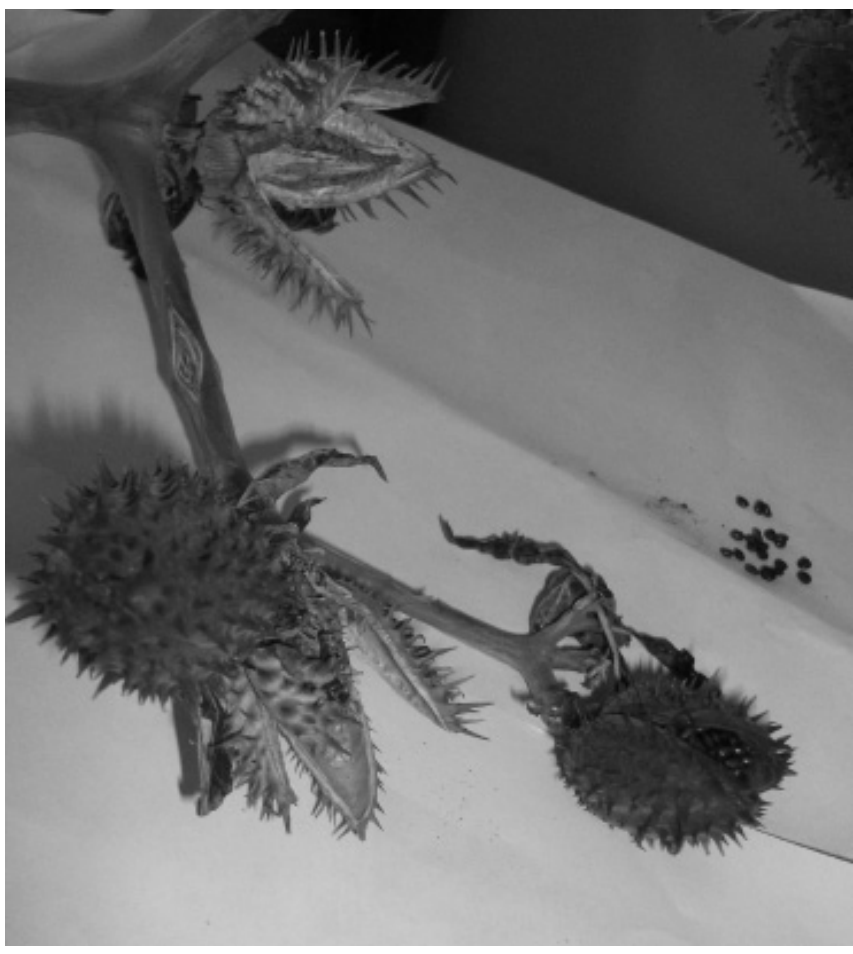

4. Andreola B, Piovan A, Dalt LD, Filippini R, Cappelletti E. Unilateral mydriasis due to Angel's Trumpet. Clin Toxicol. 2008;46:329-31.

5. Diker D, Markovitz D, Rothman M, Sendovski U. Coma as a presenting sign of Datura stramonium seed tea poisoning. Eur J Intern Med. 2007;18:336-38.

6. Köse R, Sahin OO, Abay E. Datura stramonium zehirlenmesine bağlı deliryum: Bir olgu. Anadolu Psikiyatri Dergisi 2008;9:54-57. 